\title{
Non-Take-Up of Social Assistance: Regional Differences and the Role of Social Norms
}

\author{
Oliver Hümbelin*
}

\begin{abstract}
This study estimates the prevalence of non-take-up of social assistance using administrative data from the Canton of Bern. Regional variation in non-take-up rates is then used to study the contextual effects of social norms with respect to welfare receipt legitimacy. Social norms are proxied with the degree of urbanity, language regions and communal voter shares of left- and right-wing parties. Multiple regression analysis, extended by several robustness checks, suggests that social norms do indeed have an impact on take-up behavior. Keywords: non-take-up, social assistance, Switzerland, regional differences, welfare attitudes
\end{abstract}

\section{Nichtbezug von Sozialhilfe: Regionale Unterschiede und die Bedeutung von sozialen Normen}

Zusammenfassung: Diese Studie nimmt eine Schätzung der Nichtbezugsquote von Sozialhilfe anhand von Administrativdaten des Kantons Bern vor. Anhand der regionalen Unterschiede werden anschliessend die kontextuellen Auswirkungen sozialer Normen auf die Inanspruchnahme von Sozialhilfe untersucht. Soziale Normen werden mit dem Grad der Urbanität, Sprachregionen und kommunalen Wähleranteilen linker und rechter Parteien angenähert. Multiple Regressionsanalysen, die mit Robustheitsprüfungen erweitert wurden, deuten darauf hin, dass soziale Normen einen Einfluss auf das Bezugsverhalten haben.

Schlüsselwörter: Nichtbezug, Sozialhilfe, Schweiz, regionale Unterschiede, Einstellungen zum Wohlfahrtsstaat

\section{Non-recours à l'aide sociale : différences régionales et importance des normes sociales}

Résumé: Cette étude propose une estimation de la prévalence du non-recours à l'aide sociale à partir de données administratives du canton de Berne. Les variations régionales du taux de non-recours sont ensuite utilisées pour étudier les effets contextuels de différentes normes sociales sur la légitimité à recourir à l'aide sociale. Les normes sociales sont approximées selon le degré d'urbanisation, les régions linguistiques et la part d'électeurs de gauche et de droite dans les partis locaux. Des analyses de régression multiples étendues avec plusieurs tests de robustesse suggèrent que les normes sociales ont effectivement un impact sur les comportements en matière de recours à l'aide sociale.

Mots-clés: non-récurrence, assistance sociale, Suisse, différences régionales, attitudes sociales

Bern University of Applied Sciences, BFH Zentrum für Soziale Sicherheit, CH-3012 Bern, oliver.huembelin@bfh.ch. 
Most Western societies provide social assistance for households that lack the resources to maintain a minimum standard of living. However, the redistributive effectiveness of such policies can be compromised if eligible recipients do not claim the benefits they are entitled to. If non-take-up rates are high, it is questionable whether antipoverty schemes are designed adequately. Several studies show, however, that nontake-up is present within OECD countries (Hernanz et al. 2004), and within many EU Member States (Eurofond 2015). Typically, non-take-up rates are higher in the case of means-tested social assistance programs, where estimates range from $20 \%$ to $60 \%$, compared to insurance-based benefits, where non-take-up rates range from $20 \%$ to $40 \%$ (Hernanz et al. 2004, 10). In this context, the observatory on Non-Take Up of Social Rights and Public Services (Odenore 2012) concluded for France that in the year 2011, social benefits with an equivalent value of 5.3 billion EURO were not taken up by people who were theoretically entitled to do so, and non-take-up is a phenomenon that needs further attention (Warin 2016). In Switzerland too, the topic gained increased interest, as indicated by ongoing research projects (Bonvin et al. 2015; Lucas et al. 2015), and since 2015, by an annual regional seminar on the non-use of social rights and social benefits. ${ }^{2}$

One question of investigation is why people don't take up the benefits they are entitled to. An argument frequently used is that the expected benefits are too low in comparison to the transaction costs of applying for social assistance (Riphahn 2001). In line with this argument, Bruckmeier and Wiemers (2012) identify the degree of need and the expected duration of eligibility as important determinants of claiming social assistance. Other authors argue that administrative errors and administrative hurdles lead to increased non-take-up rates (Currie 2004; Neuenschwander et al. 2012; Van Oorschot 1991; Van Oorschot 1998; Van Oorschot 2002). These can take the form of direct administrative effects, which occur when administrators wrongly decide to reject a claim, as well as indirect administrative effects, which arise from administrative arrangements that discourage eligible people from applying for benefits. Furthermore, other studies emphasize the role of stigmatization (Kayser and Frick 2000; Moffitt 1983). They argue that claiming benefits is prone to a stigma that induces social costs, which may deter potential recipients from claiming any benefits they are entitled to. While Hernanz et al. (2004) consider psychological and social costs as one of the main determinants of the high levels of non-take-up

1 The present study was conducted as part of the project Inequality of Income and Wealth in Switzerland that was funded by the Swiss National Science Foundations. Tax Data was kindly provided by the cantonal tax administration of Bern. The author wishes to thank Ben Jann, Robert Fluder, Rudolf Farys, Renate Salzgeber and three anonymous reviewers for their helpful comments on earlier versions of this paper. Further thanks go to the Social Security Research Group of the Bern University of Applied Sciences for inspiring discussions as part of an internal presentation of the research outline. 
for most welfare benefits, Daponte et al. (1999) argue against the high importance of stigma effects. By doing a special survey with people below the poverty threshold that did not apply for the food stamp program in the US, they find that the lack of information explained non-take-up better than previously assumed stigmatization, which was rarely reported as a reason not to take up benefits. It is, however, possible that results were influenced by the setting of the study itself, as it is reasonable that the information provided as part of the study reduced the previously present fear of stigmatization. In a recent nationally-representative survey in the UK, Baumberg (2016) found that one quarter says a stigma-related reason would make them less likely to claim, which indicates that the fear of stigmatization is indeed considered as part of the claiming decision. This is, however, no proof that stigma leads to a decline. Given the difficulties to operationalize and isolate the effect of stigmatization with respect to the take-up behavior, Currie (2004) even claims that it may be impossible to devise a definitive test of the "stigma hypothesis." While the presence of the effect of some factors is quite well studied (e. g., the degree of need and expected duration of eligibility), whether psychological and social costs should be considered as relevant to explain high non-take-up quotas must be clarified further.

Given this background, this paper follows two main goals. First, using tax data that allows fine-grained non-take-up rates to be estimated regionally, it aims to exploit the regional variation in order to study if differing social norms influence non-take-up. As stigmatization occurs as part of social interactions, it can be hypothesized that it must be closely related to social norms. In a context where norms regard social assistance negatively, the fear of stigmatization is increased, whereas in areas where norms are more benevolent, take-up of social assistance might be easier. Social norms in this study are proxied with parliamentary election results on a communal level. The social norms thesis is tested against other reasonable explanations for differing non-take-up, such as the urban-rural divide, differences in economic structure, population density and degree of need. Second, although non-take-up rates may be assumed to be high in Switzerland, the evidence is scarce. Non-takeup estimations for Switzerland are absent in recent academic literature, and those estimates for Switzerland that do exist are based on survey data with incomplete information on the financial situation of potential recipients (e.g., information on wealth is missing). This study, therefore, also aims to compile figures on the prevalence of non-take-up in Switzerland using an administrative data approach which should lead to a more accurate estimation.

\section{Stigma, welfare attitudes and why norms might affect take-up behavior}

Many scholars who study the effect of stigma incorporate Goffman's $(1963,6)$ definition of stigma as "the phenomenon whereby an individual with an attribute 
deeply discredited by his/her society is rejected as a result of the attribute." While stigma is thus described as an attribute of individuals, Goffman also clearly claims that the negative connotation of this attribute is constructed on the societal level. Accordingly, Link and Phelan (2001) have criticized stigma researchers' tendency to focus too exclusively on the individual level. Stigma should also be studied as part of social labeling. As norms regarding benefits differ across social groups, it might be fruitful to study how social and psychological costs affect take-up behavior in a way that pays particular attention to variation of social norms.

The field of welfare attitude research seems to be a quickly advancing area that provides insight on how and to what degree attitudes towards benefit claiming may vary (see also Van Oorschot et al. 2017). Walker et al. (2013), for example, found that the shame of poverty and stigma related to social benefits seems to be something universal that can be found in many countries, a finding Harrington (1962) already pointed to in the 60s. On a more general level, Staerklé et al. (2012) develop a social psychological theory on welfare attitudes, based on the idea that normative beliefs are central to maintain social order, and that these beliefs are anchored in the everyday experiences of citizens. To what degree receiving welfare benefits is seen as a right or as something shameful is strongly dependent on the moral communities in which individuals are embedded. Thus, communities are a key factor to understand welfare legitimacy. Using the European Social Survey to study their theory in 28 European countries, they show that contextual country features like social expenditure and the level of unemployment do indeed shape the perception of social risk and welfare legitimacy. They furthermore conclude that a fruitful further step would be to incorporate a measure of the dominant normative context or the ideological climate. "People are likely to be aware of the dominant norms prevalent in their societies and disseminated through media and public discourses" (Staerklé et al. 2012, 35). Community-specific norms may prove to be a powerful context level influencer on people's positioning towards welfare attitudes. Roosma et al. (2016) took up this endeavor and showed that perceived overuse (welfare fraud), but also underuse (non-take-up), are both present in Europe and that the perception of both varies regionally. In Southern and Eastern European countries, the perception of underuse is strong, while the Anglo-Saxon countries stand out as countries with a high average level of suspiciousness as to benefit abuse. ${ }^{3}$ Because of the relative lack of reliable information on the actual non-take-up rate in all studied countries, the authors conclude that people do not build their judgment on facts about overuse and underuse. Rather, the perceptions seem to be driven by ideology beliefs. They show that people with right-wing ideology believe that there is more welfare fraud as compared to left-wing people. However, they also observe

3 For Switzerland, the authors report below average perception of over- and underuse of welfare benefits. 
strong contextual level effects. In countries where public discourse supports strong negative images of welfare recipients, the level of perceived welfare abuse is higher.

Why and to what degree actual take-up and non-take-up of benefits vary regionally is studied less rigorously. There are studies that report regional differences in non-take-up, which indicate that social or psychological costs may vary with the context and that contextual factors have a significant impact on take-up behavior. Non-take-up studies for Germany, for example, revealed higher non-take-up quotas in Eastern Germany than in Western Germany (Kayser and Frick 2000; Riphahn 2001). Kayser and Frick (2000) explained the difference because of the history of rigid socio-political structures in the former East Germany, where people were obliged to work and the social assistance program included punishment for those able to work but who did not. There are also several studies that find a strong urbanrural divide (Becker and Hauser 2005; Bruckmeier and Wiemers 2012; Riphahn 2001). Non-take-up seems to be higher in rural areas because the protective shield of anonymity is missing in sparsely populated areas. The more people know each other in a community, the more likely claimants are to be exposed.

While some studies already found regional differences in welfare attitudes and take-up behavior, to the best of my knowledge, both aspects have not yet been brought together empirically. The subsequent analysis contributes to the literature by testing how stable the link between different proxies for welfare attitudes and non-take-up rates are. It can be hypothesized that social norms with respect to social assistance play a major role in explaining non-take-up. It seems plausible that in a context where people are more benevolent towards social assistance, take-up has lower social costs, while in areas with aversion towards social assistance, social costs are increased.

To help the reader to understand the subsequent methodological decisions and the following results, the next section provides a short description of the organization of social assistance in Switzerland, and a summary of previous studies that address non-take-up in Switzerland. The section closes by formulating three hypotheses on how norms differ regionally in Switzerland and how that might influence take-up behavior.

\section{Social Assistance, non-take-up and normative heterogeneity in Switzerland}

In Switzerland, working life risks are covered by three main schemes (Champion 2011). The primary mode of offsetting the risks faced by the unemployed is federal unemployment insurance. Invalidity insurance provides financial resources for those who are not able to work for health-related reasons. Social assistance is the last safety net. It is designed for individuals who do not reach the minimum standard of living on their own and are not covered by other institutions of social 
security. Social assistance is claimed by individuals who are long-time unemployed and who have exhausted their entitlement to regular unemployment benefits ${ }^{4}$, as well as those who work or receive other social benefits, yet still do not reach the minimum standard of living. The provision of social assistance in Switzerland is organized on a subnational level - the cantons - rather than on a national level. From an international perspective, it is rather unusual that a national law on social assistance is lacking, but the Swiss Conference on social assistance - a private union of professionals - defined guidelines that have been made binding in many cantons through cantonal laws. While basic concepts on social assistance are very similar, cantonal variation does exist. Cantonal legislation especially differs regarding upstream demand-related benefits that supplement social assistance. There are cantons that provide up to eight instruments parallel to social assistance, such as family, ageing and care allowances (BFS 2015). This cantonal heterogeneity adds complexity to studies of social assistance and non-take-up in Switzerland that needs to be addressed adequately.

Because postwar Switzerland experienced a period of near full employment, for several decades social assistance played a minor role (Champion 2011). Only with the economic crisis of the 1990s did longtime unemployment become a social problem and the societal importance of social assistance grow. Reliable figures on social assistance quotas, however, have only been available on national level since 2005, when the Federal Statistical Office implemented regular surveys on social assistance. According to the latest figures in 2016, 273273 individuals live with the help of social assistance, and the national social assistance quota is 3.3\%.

Due to specific data demands, the non-take-up of social assistance is studied neither systematically nor on a regular basis. As in other countries, only fragmented findings exist for Switzerland. Based on 1992 data, Leu et al. (1997) report nontake-up rates ranging from $45 \%$ to $86 \%$, depending on the definition of social assistance. Fluder and Stremlow (1999) report similar non-take-up rates (66\%) and observe substantial regional differences. As has been found in other countries, non-take-up seems to be lower in urban areas than in rural areas. Years later, Crettaz et al. (2009), on the basis of the Swiss Labour Force Survey (SLFS), found that in 2005 , a share of $28.2 \%$ of the population below the poverty line did not have the support of social benefits. It is unfortunate that more recent estimations are lacking, particularly since the public discourse on social assistance recipients has recently become harsher in West Europe (Larsen 2008; MacDonald et al. 2014; Sage 2012), where high levels of social expenditure have come under political pressure from neo-liberal movements, and where the shift from social to penal regulation of social problems has been clearly evidenced (Wacquant 2009). As a survey among applicants for social assistance showed (Neuenschwander et al. 2012), the alleged increase in fraud and the general blaming of recipients in the media affects self

$4 \quad$ The period of entitlement differs with age and the period of work before being unemployed. 
perception of those in need in a negative way. A newer non-take-up estimation would therefore be of interest. By consulting official statistics on poverty (SILC), Schuwey and Knöpfel (2014) presume that the non-take-up quota in recent years must be around $30 \%$ to $50 \%$. However, because information on wealth is missing and wealth is an important criterion for eligibility, and because cantonal heterogeneity with respect to take-up regulations is high, it is not possible to estimate exact non-take-up quotas from the available surveys in Switzerland.

As Switzerland and most European countries are not homogenous with respect to normative ideology, it can be hypothesized that moral communities that are decisive for an individual's behavior are not necessarily only nations. The question arises which dimensions are vital to study contextual factors and how normative ideology should be measured with sub-state context level analysis.

By studying the political geography in Switzerland, Linder et al. (2008) could show that there are several rather constant cleavages in Switzerland that can be referred to as moral communities with shared beliefs on social order. In line with Hermann and Leuthold (2003), they underline the importance of the urbanrural divide. People with the same social position vote more social-liberal in a city, compared to individuals in the countryside, which tend to favor more conservative views. It, therefore, can be hypothesized:

H1: The social costs of receiving social benefits are reduced in cities where attitudes towards the welfare state are more liberal than in the countryside. This is why it is expected that non-take-up rates are lower in cities.

A second prevalent cleavage relates to language regions. Linder et al. (2008) show that with respect to welfare politics, the French and the Italian part more often vote in line with left politics and the German part tends to be more conservative-right wing oriented. In line with these findings, a second hypothesis for the bilingual Canton of Bern can be formulated:

H2: The social costs of receiving social benefits are reduced in French-speaking parts where attitudes towards the welfare state are more liberal than in German-speaking parts. That's why it is expected that the non-take-up rate in the French part is lower.

Empirical studies generally indicate that people with left-wing sympathies are in favor of a more generous redistribution (Gelissen 2000; Jaeger 2006) and perceive the current access to the welfare state as too strict (Roosma et al. 2016), while rightwing sympathizers see the welfare state as too generous and tend to favor policies which restrict access to benefits. To pick up these thoughts for the current study, it seems to be promising to look at the political milieu of communities, as Switzerland is organized in a federal way (nation, cantons and communities), and communities are an important point of reference for everyday experiences of individuals. The third hypothesis reads as follows: 
H3: The social costs of receiving social benefits are increased in right-wing oriented communities, compared to more liberal left-wing oriented areas. That's why it is expected that non-take-up rates are higher in right-wing communities respectively and lower in left-wing communities.

\section{Data and methods}

\subsection{Tax data for Canton of Bern}

International studies often emphasize the data-related challenges that complicate endeavors to estimate valid non-take-up quotas (Hernanz et al. 2004). Bargain et al. (2012) attribute the high inter-country variations of non-take-up to measurement problems as well. They identify, for example, large discrepancies between two US studies that analyzed non-take-up for the same benefit. They, therefore, conclude that the methodological approach might influence the results. Non-take-up estimations based on surveys tend to overestimate non-take-up (Blank 1997; Hernanz et al. 2004), because of missing information on wealth (Becker and Hauser 2005; Whelan 2010) and error measurement errors in income data (Frick and Groh-Samberg 2007).

This study implements a non-take-up estimation approach based on administrative data by comparing official social assistance statistics to the results of eligibility simulations using tax data. The estimation is conducted using micro tax data for the Canton of Bern for the year 2012, which was provided by the cantonal tax agency as part of the SNF-project "Inequality of Income and Wealth in Switzerland." At the time of the analysis, this was the most recently available tax data. A consolidated version of tax data has only been available with a lag of up to three years, since values might change because of objections or missing documents. To be able to identify income on the household level, it is furthermore needed to link tax data with register data on housing, which, because of data quality, has only been possible since 2012. The linkage procedure needs a formal authorization, which was received for the current project. That is why the data used provides detailed information on the financial situation of households. ${ }^{6}$ Most importantly, tax data includes valid information on housing and capital wealth, so that eligibility can be accurately determined. Because tax data encompassed nearly the total population coverage, it is possible to estimate non-take-up rates for the canton as a whole, as well as for each municipality.

5 http://inequalities.ch/.

6 Households are typically not fully identified in tax data as tax forms do not always represent households. In some situations, several household members fill in their own tax forms, like nonmarried couples who live together or when young adults live with their parents (Hümbelin and Farys 2016). A special feature of the Bern tax data from 2012 is that tax subjects' households were determined by linking the tax data to the housing register. 
Since no national law on social assistance exists in Switzerland, cantons maintain different schemes, and substantial intra-country heterogeneity exists. Hence, non-take-up estimations have to be carefully tailored to regional conditions. It, therefore, seems appropriate to focus on just one canton. The Canton of Bern is the second most populated canton with 990000 inhabitants living in 379 communities (2012). It covers major urban and rural areas, is bilingual (German/French) and varies highly between communities with respect to political party support. It, therefore, seems to be an appropriate canton to study contextual differences.

\subsection{Determining social assistance eligibility}

Eligibility is basically determined by comparing the available economic resources of households to the eligibility threshold. If the financial resources of a given household fall below the threshold line, this household is technically entitled to social assistance. While in theory, the procedure is quite simple, special rules and data restrictions introduce hurdles that need to be overcome in order to attain a sound estimation of non-take-up quotas. For one thing, social assistance is not taxed in Switzerland, so income from social assistance is not recorded in tax data. Hence, this paper implements a two-step approach to estimate non-take-up quotas. First, the number of eligible individuals is estimated based on tax data. Then this number is compared with official statistics on social assistance beneficiaries. As both datasets cover the full population, it is possible to estimate non-take-up quotas by comparing them.

The procedure this study uses to determine eligibility is closely tailored to the means-testing procedure for the Canton of Bern, which a social assistance office would follow (BKSE 2016; SKOS 2016). The check of economic resources includes checking the income from employed- and self-employed earnings, and income from wealth. It also checks if households receive health care premium benefits. This is an important issue, as the qualifying procedure in the Canton of Bern is quite generous. Roughly $30 \%$ of the population qualifies for health care premium benefits. Note: The check implemented for health care premium benefits varies according to household composition, the region where one lives, and the income level without social assistance. The procedure additionally checks if there are other social security benefits, such as regular unemployment benefits, pensions, or benefits for the disabled, which might tip the household income over the eligibility level. Finally, the procedure checks if households possess moveable assets above the allowed exemption limits, which means it is tested if individuals hold wealth over $4000 \mathrm{CHF}$ per adult or $2000 \mathrm{CHF}$ per child and not more than $10000 \mathrm{CHF}$ per family.

The eligibility level is determined based on the size-specific basic household living needs, and is regionally tailored by means of an approximation of the cost of housing ${ }^{7}$ and health care premiums from region to region. This leads to an eligibil-

$7 \quad$ The procedure implements a threshold for housing varying according to the usual local prices; similar to the procedure of a social service (see table A-1 in the appendix). 
ity threshold of roughly $28000 \mathrm{CHF}$ annual income for a one-person household, while for a couple with two children, the threshold is around 59710 CHF. Social assistance in the Canton of Bern is further combined with so-called "benefits with incentives." These follow the idea that people will continue to make an effort to earn an income independent of social assistance if additional benefits are provided for beneficiaries who simultaneously participate in the labor market. This leads to a de facto increase of the eligibility threshold related to income already earned. Benefits with incentives, however, don't exceed 10200 CHF per year for households with a maximum of 5 persons, and $12000 \mathrm{CHF}$ for larger households.

Finally, individuals with an old-age and survivor pension or an invalidity pension also have the possibility to apply for supplemental benefits outside of social assistance. As these supplemental benefits don't have to be taxed, it is not possible to check them, but since the take-up rate for these benefits is known to be high, households with either an old-age and survivor pension or an invalidity pension will not be counted as among the eligible population. The simulated mean-testing procedure can be summarized in the formula below:

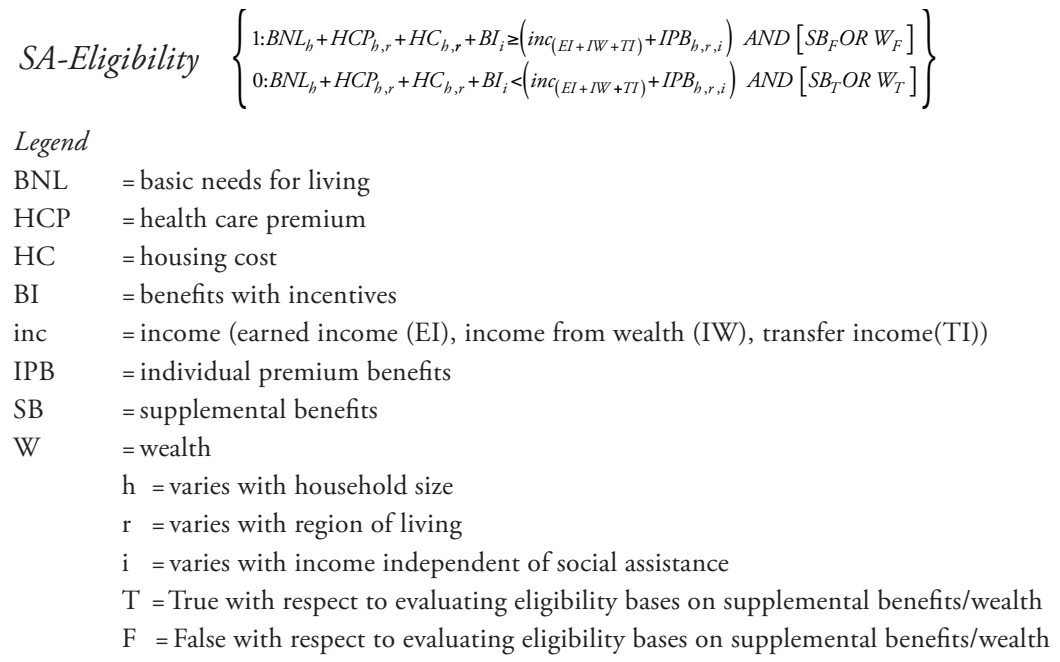

There are, nevertheless, aspects of the means-testing procedure that cannot be addressed directly, which is why the following results are still estimations. First, social assistance can be applied for on a monthly basis, but tax data collects information annually. This issue can be addressed to some degree by excluding short-term social assistance beneficiaries from the social assistance statistics (see next paragraph). Furthermore, there are incomes that don't have to be taxed, yet are still considered in a 
real-world mean-testing procedure. This is important for young adults in education who receive scholarships, grants or financial support from parents. It is important for retirees as well, as they have means of financial support beyond those previously mentioned. This issue is addressed in this paper by narrowing the population of study to the working-age population (25-63/64). Finally, while the rules on social assistance eligibility are very clear, the social assistance offices are encouraged to treat cases individually, which may lead to exceptional treatment on a case-by-case basis. This, of course, cannot be modelled.

Based on this procedure, it is estimated that $5.7 \%$ of the population between the ages of 25 and 63/64 living in Bern would be entitled to receive social assistance.

\subsection{Estimating the non-take-up quota}

To estimate the non-take-up quota, the quota of entitled individuals is compared to the official social assistance quota. To make the social assistance quota comparable to the results based on tax data, a recalculation is needed - as was carried out by the Federal Statistical Office (Braun and Boruvka 2016). The correction included agespecific limitations and further excluded individuals with foreign nationalities, who may be eligible to apply for social assistance, but may not be obliged - depending on residency status - to fill in the same tax forms as Swiss citizens because they are taxed at source. Additionally, beneficiaries with less than four months of support from social assistance were excluded (short-term social assistance beneficiaries).

Table 1 shows the quota of eligibility, the corrected social assistance quota and the corresponding non-take-up quota. By following this procedure, this study concludes that $26.3 \%$ of those who would be entitled to social assistance don't take it. The baseline estimation is extended with upper and lower bound estimates to get a sense of the sensitivity of the estimation to the eligibility simulation. This includes $\mathrm{a}+/-5 \%$ adjustment of the household-specific eligibility threshold. As shown in the table, the non-take-up quota is relatively stable in response to a lowering of the threshold, while the increase of the eligible population is higher when subjected to an increase of the threshold.

Table $1 \quad$ Non-take-up of social assistance for working-age population ${ }^{\mathrm{a}}$ in Canton of Bern

\begin{tabular}{ccc}
\hline $\begin{array}{c}\text { Quota of eligible } \\
\text { (Estimation [min-max] })\end{array}$ & Corrected SA-Quotac & $\begin{array}{c}\text { Non-Take-Up Quota } \\
\left.\text { (Estimation [min-max }]^{b}\right)\end{array}$ \\
\hline $5.7 \%$ & $4.2 \%$ & $26.3 \%$ \\
{$[5.1 \%-7.0 \%]$} & & {$[17.6 \%-40.0 \%]$} \\
\hline
\end{tabular}

a Estimation includes individuals between the ages of 25 and $63 / 64$.

${ }^{b}$ Min- and max-scenario refer to eligibility thresholds of minus $5 \%$ and plus $5 \%$.

' correction includes the exclusion of individuals below 25 , individuals in the age of retirement, foreign nationals that are not part of the common taxing procedure and short time beneficiaries ( $<4$ months). 


\section{Regional differences of non-take-up and possible explanations}

As shown, social assistance does not reach every member of the target population. To explore regional variation within the Canton of Bern, in a next analytical step, communal non-take up quotas were calculated by calculating the proportion of the eligible population out of tax data subtracted by the official number of beneficiaries for each community. Since the eligibility simulations induce some inaccuracy by implementing generalized assumptions, the level of the communal estimates should

Table 2 Operationalization and descriptive statistics of variables used to analyze regional variation $(n=312)$

\begin{tabular}{|c|c|c|c|}
\hline Variable & Operationalization & Descriptives & \\
\hline Urban/rural & $\begin{array}{l}\text { Typology of communities according to the } \\
\text { Federal Statistical Office }\end{array}$ & $\begin{array}{l}\text { Cities: } \\
\text { Agglomeration: } \\
\text { Rural com: }\end{array}$ & $\begin{array}{r}7(2.3 \%) \\
74(23.7 \%) \\
231(74.0 \%)\end{array}$ \\
\hline Language region & $\begin{array}{l}\text { Typology of communities according to } \\
\text { assignment of the Federal Statistical Office }\end{array}$ & $\begin{array}{l}\text { German: } \\
\text { French: }\end{array}$ & $\begin{array}{r}280(89.7 \%) \\
32(10.2 \%)\end{array}$ \\
\hline Left-right-scale (cont.) & $\begin{array}{l}\text { Voter-shares of Swiss People's Party minus } \\
\text { Voter-shares of Social Democratic Party. } \\
\text { Parliamentary vote } 2011\end{array}$ & $\begin{array}{l}\text { 25\%-percentile: } \\
50 \% \text {-percentile: } \\
\text { 75\%-percentile: }\end{array}$ & $\begin{array}{l}11.6 \\
22.4 \\
34.0\end{array}$ \\
\hline Left-right-scale (cat.) & $\begin{array}{l}\text { Categories are built based on } 25 \text { and } \\
75 \text { percentiles }\end{array}$ & $\begin{array}{l}\text { Cat1: middle-left wing: } \\
\text { Cat2: moderate middle: } \\
\text { Cat3: right-wing: }\end{array}$ & $\begin{array}{r}78(25.0 \%) \\
165(52.9 \%) \\
69(22.1 \%)\end{array}$ \\
\hline \% empl. in sec. 1 & Employees in primary economic sector & $\begin{array}{l}\text { 25\%-percentile: } \\
\text { 50\%-percentile: } \\
\text { 75\%-percentile: }\end{array}$ & $\begin{array}{r}0.2 \\
16.3 \\
72.8\end{array}$ \\
\hline$\%$ empl. in sec. 2 & Employees in secondary economic sector & $\begin{array}{l}\text { 25\%-percentile: } \\
\text { 50\%-percentile: } \\
\text { 75\%-percentile: }\end{array}$ & $\begin{array}{l}14.8 \\
23.4 \\
34.2\end{array}$ \\
\hline \% empl. in sec. 3 & Employees in tertiary economic sector & $\begin{array}{l}\text { 25\%-percentile: } \\
\text { 50\%-percentile: } \\
\text { 75\%-percentile: }\end{array}$ & $\begin{array}{l}13.3 \\
50.0 \\
65.4\end{array}$ \\
\hline Population density & Population per km² & $\begin{array}{l}\text { 25\%-percentile: } \\
\text { 50\%-percentile: } \\
\text { 75\%-percentile: }\end{array}$ & $\begin{array}{r}68.9 \\
135.4 \\
301.1\end{array}$ \\
\hline$\%$ working poor & $\begin{array}{l}\text { Share of persons with at least one entry of } \\
\text { earned income over a year among eligible } \\
\text { households of a community }\end{array}$ & $\begin{array}{l}\text { 25\%-percentile: } \\
\text { 50\%-percentile: } \\
\text { 75\%-percentile: }\end{array}$ & $\begin{array}{l}53.3 \\
64.0 \\
73.1\end{array}$ \\
\hline $\begin{array}{l}\text { Average gap to } \\
\text { eligibility threshold }\end{array}$ & $\begin{array}{l}\text { Average gap to eligibility threshold in CHF } \\
\text { of annual income among eligible house- } \\
\text { holds of a community }\end{array}$ & $\begin{array}{l}\text { 25\%-percentile: } \\
50 \% \text {-percentile: } \\
75 \% \text {-percentile: }\end{array}$ & $\begin{array}{r}4503 \\
18008 \\
21577\end{array}$ \\
\hline
\end{tabular}

a The original categories "isolated cities" and "core city of an agglomeration" were put together to the category "cities." 
be interpreted with care. This is especially true for small communities where small deviations already lead to inaccurate estimations. Therefore, communities are excluded from further analyses that reach - based on the communal distribution of non-take-up quotas - below or beyond the $5 \%$ and $95 \%$ percentile, respectively (see figure A-1 and A-2 in the appendix for boxplots with and without outliers). This leaves a sample of 312 communities with an average non-take-up quota of $41.1 \%$ and a standard deviation of $31.4 \%$.

To analyze regional non-take up within the Canton of Bern, the tax data based information were matched to key figures for Swiss communities for the year 2012 that are made publicly available through the Federal Statistical Office (BFS 2013). Table 2 lists the variables used for regression analysis later on. It describes how they are operationalized and provides descriptive information on the communities in the Canton of Bern. In 2012, seven communities qualified as cities. 74 (24\%) are classified as being part of the agglomeration, and the majority (74\%) are rural communities. The canton is mainly German-speaking ( $90 \%$ of the communities) with a French-speaking part (10\%). The working population is strongly engaged in the service sector (the median share of employees in the tertiary sector in a community is 50\%), while industrial (23\%) and agricultural (23\%) labor are still present.

\subsection{Differences between urban and rural, language region and along political orientation}

The descriptive analysis shows results which suggest that social costs related to social norms indeed might influence non-take-up as stated in the three formulated hypotheses. First, there is a gap between the German and the French region. On average, non-take up is higher in the German region (median non-take-up $=45.6 \%$ ) than in the French (median non-take-up $=16.2 \%$ ). This might be due to different perceptions of claiming social benefits which can be associated with differing social costs as stated in hypothesis 1 . Second, non-take-up is on average lower in cities (median non-take-up $=12.2 \%)$ than in agglomerations (median non-take-up $=28.2 \%)$ and rural communities (median non-take-up $=50.0 \%$ ), as was visible in previous studies. Often, it is argued that population density is a key factor for explaining the urban-rural divide. In small communities, beneficiaries can be easily identified, possibly making them an easier target for stigmatization than social assistance recipients in densely populated cities which grant greater anonymity. Besides the mere fact of the population density, however, there are other social costs related to the stigma that may explain the rural-urban divide; namely, social costs related to differing norms regarding social assistance. It is said that the population in cities is more socially liberal, which leads to higher take-up rates than in rural areas, where the milieu is more conservative and the dislike of social assistance is greater, thus leading to higher non-take-up rates as is stated in hypothesis 2 . 
Figure $1 \quad$ Non-take-up quotas of municipalities of the Canton of Bern along a left-right political scale

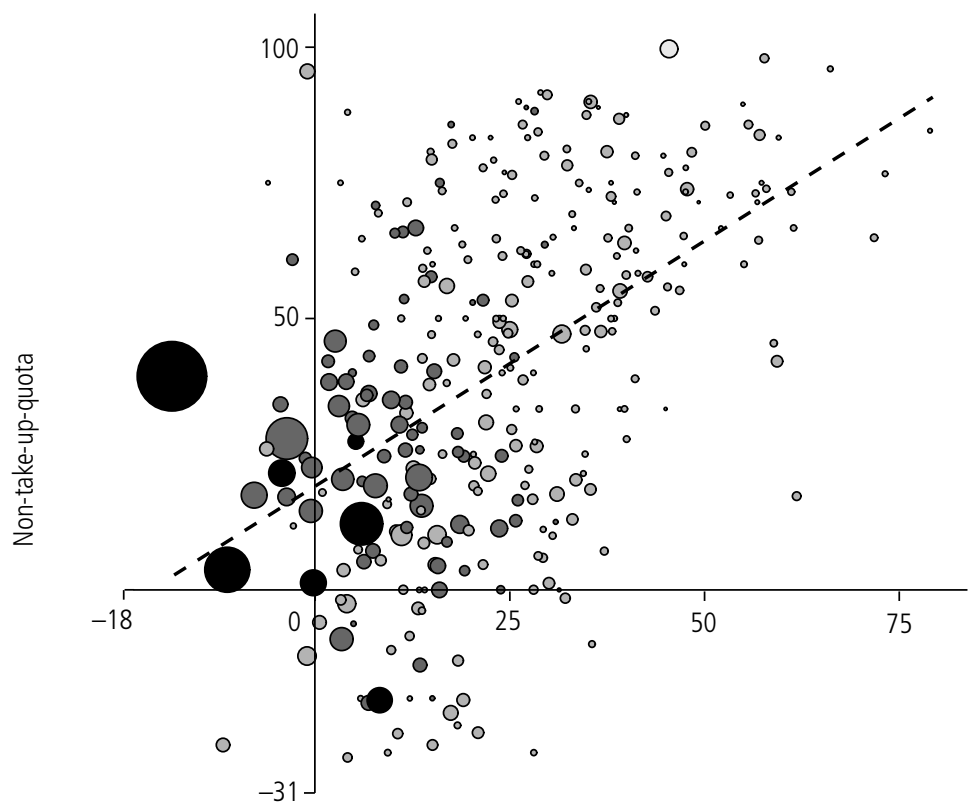

Left-right-scale

Type of municipality

- City $\bigcirc$ Agglomeration $\bigcirc$ Rural Community

Remarks:

Circles are drawn in relation to population size.

Left-right-scale $=$ voters share Swiss People's Party minus Social Democratic Party (parliamentary elections, 2011).

The line visualizes the (linear) correlation between the left-right scale and the non-take-up quotas.

When it comes to the measurement question, it has to be stated that there is no survey in Switzerland where it is possible to directly aggregate welfare attitudes on a communal level to build contextual-level factors. As outlined in the theoretical section, it calls for looking at political orientation instead. With respect to this, the outcome of parliamentary votes seems to be a plausible way to measure if people in a region rather favor left-wing oriented than right-wing oriented politics which stand for a favorable respectively harsh milieu with respect to claiming social benefits. Parliamentary votes are held every four years, are publicly available and can easily be matched to the communities. Fivaz (2015) shows that party profiles in Switzerland with respect to social assistance are quite heterogeneous, with a strong 
left-right divide. The Social Democratic Party (SDP), which traditionally stands for more equality and combatting poverty, is strongly in favor of maintaining generous social assistance benefits. The other end of the left-right pole is held by the Swiss People's Party (SPP), for whom the reduction of social assistance benefits is a prominent issue on the agenda. The SPP was able to expand their voter base in the years after 2000 and are currently the strongest party in Switzerland, while the SDP lost voters but remain the second strongest party (Rennwald and Zimmermann 2016).

To study to what degree non-take up rates vary with respect to political orientation, a left-right scale based on the parliamentary outcome of 2011 was calculated by subtracting the SDP-voters' share (left wing) from the SPP-voters' share (right wing). ${ }^{8}$ This results in a scale that measures if people in a community favor left or right wing politics or if political forces are rather balanced. As seen in Table 2, the median value of +22 indicates that in an average community in Bern, the share of the right-wing (SDP) outnumbers the share of the left-wing (SPP) voters. Still there are some communities where the left-wing party dominates.

Figure 1 displays the communities of the Canton of Bern in a scatterplot with non-take-up quotas on the y-axis and a left-right-scale, based on the parliamentary vote, on the x-axis. As seen in the figure, cities are, on average, more left-oriented than agglomerations that take on more balanced values on the left-right scale. In rural communities, there is quite some variation. There are rural municipalities that are similar to cities in regard to their political orientation, while there are also municipalities that are very conservative. As is clearly visible, the scatterplot suggests that there is a relationship between social norms - represented as vote share - and non-take-up quotas, and this relationship is strongly driven by the rural communities (see also box-plots in figures A-1 and A-2 in the appendix).

This bivariate analysis hints in the direction of the formulated hypotheses. As outlined already in the theoretical section, there is an empirical overlap with respect to the dominant language/urbanity of a region and political orientation. In a next step, with the help of regression analysis, it is determined if the degree of urbanity, language region and political orientation point to different facets of social norms which influence non-take up, or if one measure dominates the others. By analyzing the variance inflation factor, it is furthermore possible to determine if multicollinearity between these three concepts reaches critical values, or if the variation in the data including all three variables is sufficient to estimate separate effects.

$8 \quad$ An alternative operationalization including parties like the Free Democratic Party or the Greens Party was tested. The index correlated strongly with the simple form of the left-right scale $(r=0.97)$, but model fit in the later regression analysis was lower. Because of that and for easier interpretation, the simpler form of the left right scale was used. 


\subsection{How might differences be explained?}

The descriptive results suggest that differing social norms do indeed influence the non-take-up rate. But do these results hold if other relevant factors are controlled for? The population density thesis is closely related, albeit with other social mechanisms. This thesis also states that non-take-up is influenced by stigma, but that the urban-rural divide is instead explained by differing population density, i. e. by exposure in rural areas and anonymity in urban areas. There are also three strong economic arguments that might explain the urban/rural divide and that might dissolve the descriptive association. First, the take-up rate in rural areas might be lower because other means of support exist in rural areas. In smaller rural communities, people traditionally rely more heavily on private support and helping each other out (Fluder and Stremlow 1999). Furthermore, if households maintain farms or large gardens, they also have the option to live self-sufficiently (Contzen 2015). Second, as farmers fear that they will have to sell their farm if they apply for social assistance, it can be hypothesized that this explains low take-up rates in rural areas that rely on farming. Third, the thesis that economic structure influences non-take-up can be developed further to encompass not only the agricultural/primary sector, but the industrial/secondary and the service/tertiary sectors as well. The economic structure influences employment opportunities, and it might therefore influence the expected duration of being in need (Bruckmeier and Wiemers 2012). People working in the dynamic tertiary economic sector are more likely to be working poor. This, for example, is true for people working in gastronomy. At the same time, people working in a tertiary sector job can expect to be back in the labor market sooner, because developments are more dynamic and the sector is the largest job provider. Both dynamics boost non-take-up. In contrast, the importance of the secondary economic sector continues to decrease, and expectations for its future are rather pessimistic. Correspondingly, if people in industrial areas are in need, they may fear having to remain in this situation for longer periods. This mechanism boosts take-up and decreases non-take-up.

As the economic structure and population density in urban and rural areas are very different, it is possible that the urban/rural divide is driven by these factors and not by differing social norms.

To test these arguments, several regression models were calculated (see Table 3). Model 1 replicates the descriptively observed differences between urban and rural areas. Expected non-take-up quotas are higher on average in rural municipalities $(+18.3)$ than in cities, while the difference between cities and agglomerations are marginal. There are also differences with respect to language regions. Non-take-up is lower in the French-speaking region (-25.3). This simple model already explains $10.3 \%$ of regional variance. While these differences could be due to differing social norms, more light is shed on the ongoing mechanism by introducing variables according to described alternative explanations. If the model is supplemented with 
Table 3 Effect estimation for communal non-take-up quotas (OLS)

\begin{tabular}{|c|c|c|c|c|c|}
\hline & Model (1) & Model (2) & Model (3) & Model (4) & Model (5) \\
\hline \multicolumn{6}{|l|}{ Urban/rural (ref.: cities) } \\
\hline $\begin{array}{l}\text { agglomerations } \\
\text { rural communities }\end{array}$ & $\begin{array}{l}3.87 \\
(3.51) \\
18.3^{* * *} \\
(3.62)\end{array}$ & $\begin{array}{c}2.64 \\
(3.25) \\
1.30 \\
(4.29)\end{array}$ & $\begin{array}{c}0.97 \\
(3.46) \\
-5.73 \\
(5.60)\end{array}$ & $\begin{array}{c}-1.42 \\
(3.34) \\
-7.60 \\
(5.42)\end{array}$ & $\begin{array}{c}4.03 \\
(3.23) \\
-8.64 \\
(4.84)\end{array}$ \\
\hline \multicolumn{6}{|l|}{$\begin{array}{l}\text { Language region: } \\
\text { (ref.: German) }\end{array}$} \\
\hline French & $\begin{array}{c}-25.3^{* * *} \\
(6.65)\end{array}$ & $\begin{array}{l}-9.90 \\
(6.59)\end{array}$ & $\begin{array}{c}-3.04 \\
(6.12)\end{array}$ & $\begin{array}{c}1.81 \\
(5.93)\end{array}$ & $\begin{array}{r}-14.4^{* *} \\
(5.23)\end{array}$ \\
\hline \multicolumn{6}{|l|}{$\begin{array}{l}\text { Left-right orientation } \\
\text { (ref.: moderate) }\end{array}$} \\
\hline $\begin{array}{l}\text { middle-left } \\
\text { right-conservative }\end{array}$ & & $\begin{array}{c}-19.0^{* * *} \\
(4.23) \\
30.3^{* * *} \\
(6.56)\end{array}$ & $\begin{array}{c}-12.6^{* *} \\
(4.17) \\
16.3^{*} \\
(6.40)\end{array}$ & $\begin{array}{r}-11.3^{* *} \\
(4.01) \\
19.4^{* *} \\
(6.16)\end{array}$ & $\begin{array}{c}-8.14^{*} \\
(3.40) \\
12.25^{*} \\
(5.40)\end{array}$ \\
\hline \multicolumn{6}{|l|}{ Economic structure } \\
\hline $\begin{array}{l}\text { \% empl. in sec. } 1 \\
\text { (ref.: sec 2) } \\
\% \text { empl. in sec. } 3 \\
\text { (ref.: sec 2) } \\
\text { log (population density) } \\
\% \text { working poor } \\
\text { log (average gap to eligibility } \\
\text { threshold) }\end{array}$ & & & $\begin{array}{l}0.69^{* * *} \\
(0.15) \\
0.76^{* * *} \\
(0.10) \\
-7.93^{* * *} \\
(1.87)\end{array}$ & $\begin{array}{l}0.49^{* *} \\
(0.15) \\
0.64^{* * *} \\
(0.10) \\
-6.57^{* * *} \\
(1.81) \\
0.39^{* * *} \\
(0.11) \\
-18.6^{* * *} \\
(5.45)\end{array}$ & $\begin{array}{l}0.38^{* *} \\
(0.10) \\
0.36^{* * *} \\
(0.10) \\
-8.85^{* * *} \\
(1.56) \\
0.31^{* *} \\
(0.10) \\
-20.8^{* * *} \\
(4.7)\end{array}$ \\
\hline Intercept & $\begin{array}{l}21.3^{* * *} \\
(2.68) \\
\end{array}$ & $\begin{array}{l}40.3^{* * *} \\
(4.90) \\
\end{array}$ & $\begin{array}{r}31.8^{*} \\
(15.8) \\
\end{array}$ & $\begin{array}{l}193.4^{* * *} \\
(56.5)\end{array}$ & $\begin{array}{l}248.67^{* * *} \\
(56.4)\end{array}$ \\
\hline n (municipalities) & 312 & 312 & 312 & 312 & 312 \\
\hline$r^{2}$ & 0.103 & 0.242 & 0.393 & 0.446 & 0.407 \\
\hline adjusted $R^{2}$ & 0.094 & 0.229 & 0.377 & 0.428 & 0.388 \\
\hline method & OLS & OLS & OLS & OLS & MM-95 \\
\hline $\begin{array}{l}\text { municipalities with |weights } \mid \\
(<0.00032)\end{array}$ & & & & & 2 \\
\hline $\begin{array}{l}\text { municipalities with } \\
\text { weights }<1\end{array}$ & & & & & 85 \\
\hline
\end{tabular}

Remarks: Significance levels: ${ }^{* * *} p \leq 0,{ }^{* *} p \leq 0.001,{ }^{*} p \leq 0.01, p \leq 0.05$. Standard errors in parentheses. All estimations apply analytical weights based on population of communities. OLS: Ordinary least square. MM-95: Robust estimation using a MMType estimation (Koller and Stahel 2011). Estimation results in robust and efficient estimations with $50 \%$ breaking points and 95\% asymptotic efficient normally distributed standard error (Rousseeuw et al. 2015).

the left-right-scale variable, as a more direct proxy for differing social norms, the variance explained is nearly doubled and the effect is stronger than the effects of the mere urban/rural variable and the dummy for the language region. Indeed, their direct effects decrease substantially, so that they no longer statistically significant differ from zero. The interpretation thereof could be that most of the difference between 
urban and rural areas and between language regions is captured by the theoretically more direct operationalization of social norms through political orientation. Model 3 adds additional control variables like economic structure (share of employees in the respective economic sector) and the log of the population density. Again, the model fit increases substantially. Model 3 explains 39.3\% of regional variance. The effect coefficients show that an increasing share of employees in the primary and the tertiary sector is associated with an expected increase of non-take-up. The effects also show that industrial areas seem to have lower non-take-up rates. This is in line with the fact that the industrial economies in the Canton of Bern are located in the French part, and controlling for this further dissolves the effect of the language dummy. This result supports the thesis of effects stemming from employment opportunities related to economic structure, and it can also be interpreted as supporting additional options to live self-sufficiently by means of farming. While Model 3, moreover, shows a strong negative effect of the logarithmic population density, further analyses not displayed here show that this effect is strongly driven by the difference between small to average municipalities and flattens out when comparing average municipalities to cities. It seems, therefore, that population density influences the take-up behavior, especially in small communities, where it is potentially possible that social assistance applicants and employees of the social service agency know each other. Model 4 is finally extended with variables derived directly from tax data. Both variables describe the degree of need and show effects in the expected way with plausible sizes. The effect of "\% working poor" can be interpreted directly: if the share of working poor among the group of eligible households increases, for example, by 10 percentage points, the expected share of non-take up increases by 4 percentage points. The effect of the average gap to the eligible threshold is of similar size. Because of the logarithmic scale the effect-coefficient divided by 100 approximates the effect of a one percent change on non-take up rates of communities. An average gap measure by annual income increases by $10 \%$ results in $10^{*}(-18.6 / 100)=-1.86$ percent point decrease of the expected non-take up rate.

Note that the effect related to the left-right scale decreased when implementing key economic explanatory variables and population density, but that the effect that remains is still statistically different from zero.

From a methodical perspective, two issues need to be clarified further. First, as the sample size is relatively small, it may be of interest if and to what degree the results are driven by single observations which are different compared to the others (outliers). Second, to what degree is collinearity present between the variables used in the model, and do they lead to critical multicollinearity that hinders the interpretation of single estimates? The robustness analysis described below focuses on how the effect of political orientation changes.

A first visual inspection of the residuals and partial leverage plots do indeed show some anomalies. One observation deviates especially strong from the others. 
Further inspections show that it is one of the large cities, indicating that the ongoing mechanisms are somehow different in the large city. Excluding this single observation leads to a small decrease of the effects of political orientation (left-middle from $-11.3^{* *}$ to $-10.4^{* *}$ and right-wing: $19.4^{* *}$ to $18.8^{* *}$ ), but not in a substantial way. More automated possibilities to check the robustness of regression models offer methods of robust regression (Jann 2010). Methods that are part of robust regression methodology are less influenced by outliers and possess desired features even if the distribution of residuals is not normal. They are, therefore, able to uncover basic associations in the data even when outliers are present. Results in Table 3 below the column of Model 5 implemented a robust regression of the MM-type. MM-type robust regressions try to balance the effective contribution of single observations by giving deviating observations less weight. The implemented estimation procedure uses $50 \%$ breaking points and $95 \%$ asymptotic normal efficiency standard errors. These are the parameters recommended by Koller and Stahel (2011) and Rousseeuw et al. (2015), and the robust regression method does indeed lead to the exclusion of two observations, the reweighting of 85 observations and a slightly reduced model fit.

The effect of the social norms variable is reduced as well, but it is statistically still significantly different from zero. All other effects are rather constant, except for the effect related to the language dummy. This can be interpreted as signifying that there might still be an effect of social norms related to cultural differences. Further research should investigate this possibility more deeply.

Further robustness checks were done to investigate how the correlation between the independent variables influences stability of effect coefficients and if they inflate standard errors. ${ }^{9}$ Variance inflation factors (VIF) can be calculated to check for the degree of multicollinearity. A variable whose VIF value is greater than 10 may merit further investigation (UCLA 2018). Based on Model (4), none of the VIF values exceed 5.0. ${ }^{10}$ The highest VIF values occur for population density and the urban/ rural-variable. Excluding either population density or the urban/rural variable does not influence the effect of political orientation estimates strongly (middle-left: $-14.5^{* * *} /-10.2^{* * *}$, right-wing: $23.6^{* * *} / 20.4^{* * *}$ ). A further robustness check was performed by excluding both variables. Mean VIF of this model falls below 2 with a value of 1.83 . While the variables contain information on employees in primary $(\mathrm{VIF}=3.2)$ and tertiary sector $(\mathrm{VIF}=2.4)$ are still above two, this is not a problem at all, as these variables are by definition correlated. Coefficients for political orientation look as follows: $-14.6^{* * *}$ middle/left, $+23.3^{* * *}$ right-wing. Further models were estimated with MM-95 robust regressions. For this model, VIF was high again for the variables for economic structure and the left-right scale. A final model

$9 \quad$ Calculating a rank correlation matrix with all independent variables indicates correlation above $|0.5|$ between urban/rural and population density $(-0.6)$, urban/rural and employees in primary sector $(0.5)$, political orientation and employees in primary sector $(-0.7)$, population density and employees in primary sector $(-0.7)$. 
with robust regression and only the variables language region, left-right, working poor and poverty gap resulted in a model with VIF values below 1.5 for all variables, an adjusted R-square of 0.31 , the exclusion of two cases and a reweighting of 140 observations with weights lower than 0.95 . The effect for political orientation remained stable: middle/left: $-13.2^{* * *}$, right-wing: +24.5 .

A summary of the robustness analysis might help to orientate: different models were calculated to check the stability of the effects related to political orientation. The robustness check, however showed that there are cases that deviate from the general pattern and there is also collinearity to some degree. It has to be noted that there are no strict rules on how deviating observations and multicollinearity should be treated. A single "true" model can, therefore, not be determined. However, over all the tested variants, the effect of political orientation remains in the theoretical expected way, reaching from middle/left: $-8.1^{*}$, right-wing: $12.2^{*}$ for Model (5) all variables used, some collinearity accepted, deviant observations weighted down to middle/left: $-13.2^{* * *}$, right-wing: +24.5 indicating that - given the data at hand - a substantially rather strong effect relating to political orientation of communities, which is a plausible proxy for attitudes toward social assistance benefits can be identified.

\section{Discussion and conclusion}

While most Western societies provide social assistance for households that lack the resources to maintain a minimum standard of living, non-take-up quotas in many countries are high. This raises questions about the causes of this phenomenon, and about whether or not the design of the welfare system is adequate to reach the target group. Other studies have already shown that economic contingencies, like the degree of need and the expected duration of being supported by social assistance, are important factors for the non-take-up of social assistance. Even though it seems common knowledge that social assistance is indeed associated with a stigma in many countries; however, whether the social costs associated with social norms also explain take-up behavior remains a subject of controversy.

The present study contributes to this debate by analyzing regional differences of non-take-up and the role of differing social norms by estimating communal nontake-up quotas for the Canton of Bern in Switzerland. These estimations are based on a comparison of eligibility simulations, based on tax data with official statistics on the beneficiaries of social assistance. The descriptive part of this article showed that there are indeed differences along known cleavages within Switzerland that support this view. Non-take up is lower in urban areas than in rural. It is also lower in the French-speaking part compared to the German-speaking part. This indicates that these divisions might reflect different perceptions of the legitimacy of welfare 
receipt that might induce different social costs with respect to claiming benefits. The empirical part further showed that social norms are proxied more directly through political orientation, measured as results from parliamentary votes. If the population of a region prefers parties promoting the reduction of social assistance, it is assumed that social costs for persons to apply for social assistance must be higher. Likewise, it is assumed that in regions where a larger share of the vote supports parties in favor of politics for poor, the social costs to apply for social assistance are lower. The descriptive results show a strong correlation for municipalities situated on a vote-based left-right-scale with non-take-up quotas. On the one hand, this overlaps with the urban-rural divide, but on the other, it is strongly driven by rural municipalities that are very heterogeneous in their political leanings. The correlation shows that non-take-up rises if the political milieu becomes more conservative. This descriptive result has been tested against a set of alternative economic explanations with multiple regression models which were extended with robustness checks for reasons of sensitivity. While alternative explanations also hold, the effects related to social norms remain. This supports the thesis that non-take-up is influenced by social norms.

The second objective of the study was to provide a current and accurate figure on the prevalence of non-take-up in Switzerland. With respect to this the study presents a first administrative data based estimations for Switzerland. The estimated non-take-up quota is a bit lower than presumed by Schuwey and Knöpfel (2014), who estimated that in Switzerland, it must be around 30\% to $50 \%$ by consulting official poverty statistics. On the one hand, this discrepancy could be due to the accuracy gained by using administrative data (having access to information on wealth), while on the other hand, it is not possible to cover the complete foreign population with tax data, because they get taxed differently in the first period after immigration - which might influence non-take-up estimation. Bruckmeier and Wiemers (2012), for example, showed that foreigners have a lower probability of taking up social assistance benefits, because they are less familiar with the welfare system than native citizens and because they tend to get more stigmatized. There are also legal reasons why foreigners tend to forego social assistance. Since the receipt of social benefits is included in the examination of the settlement permit. It might, therefore, be hypothesized that the non-take-up quota might be even higher if all categories of foreigners could be included.

Besides the fact that this study is not able to address the situation of nontake-up for specific categories of foreigners, there are other drawbacks that might be addressed in a follow-up study. With the approach chosen, it is, for example, not possible to distinguish between the persistent and the temporary form of non-takeup (Bruckmeier and Wiemers 2012). A combination of episodic earned income data combined with episodic data on social benefits and on wealth would make that possible, and it would further increase the accuracy of non-take-up estimates. 
Furthermore, the study excluded young adults and pensioners as their financial situation is covered by other instruments, like scholarships and supplementary benefits, which are not covered in the data this study used. However, from a theoretical perspective, it would be of interest to know more about the take-up behavior along the life course and also between age cohorts.

From a substantial point of view, a further limitation of the study is that it remains unclear how different regional norms translate to actual behavior. As the social services are organized on the communal level, this might be a result of different administrative setups that hamper or facilitate the take up of social assistance. It could also be the result of a reasoned decision of individuals. It is plausible that the fear of stigmatization leads to increased social costs and that this process reduces the willingness to take up social benefits. Furthermore, Warin (2016) points out that not taking up social benefits, in the case that the person in question is completely aware of its possibilities, also refers to an act of disagreement between the user and the rights granted that fundamentally questions the given social policy. In this vein, Leresche and Tabin (2016) point out that non-take-up can be an expression of an autonomous act of social criticism that opens up the field for alternative forms of support, such as private social services, soup kitchens, exchange platform for objects and services or occupying vacant apartments, which must be respected (Tabin and Leresche 2016). All these three possible interpretations of how social norms influence behavior are in line with the given results. Additional research is needed to further clarify how different social milieus and norms relate to take up behavior.

Compared to other countries, the non-take-up quota of the present study is rather low (Hernanz et al. 2004). This might be explained by the professional structures in Switzerland that lead to comparably better coverage with social assistance. Nonetheless, non-take-up is present in Switzerland as well. It can be assumed that it is especially present if individuals earn some income and if they are around the threshold for the minimum standard of living. As the threshold varies by household size, regions of living and other income sources, it is difficult for those affected to determine on their own if they qualify for social assistance. Some will contact a social security office to clarify their situation. Others, however, will try to live with scarce financial resources, ask for support in their social environment, get into debt and even renounce claiming health support if it is not immediately vital (Bodenmann et al. 2014). More generally, they miss the opportunity for a professional consultation on how to improve their situation. Non-take-up is neither only a private matter only, nor merely a question of injustice, as the debts and precarious existences of individuals can increase long-term costs for society. This might include expensive debt restructuring or costs related to long-term health problems (Knüsel and Colombo 2014). Furthermore, if children live in the household, the risk of passing on poverty to them is increased because worrying how to master the episode of financial hardship might suppress other family ambitions and thus, 
investment in the education of their children may no longer be the first priority. It is therefore questionable if social costs and stigmatization are adequate pillars of efficient poverty policies.

\section{References}

Bargain, Olivier, Herwig Immervoll, and Heikki Viitamäki. 2012. No Claim, No Pain. Measuring the Non-Take-Up of Social Assistance Using Register Data. The Journal of Economic Inequality 10(3): 375-395.

Baumberg, Ben. 2016. The Stigma of Claiming Benefits: A Quantitative Study. Journal of Social Policy 45(2): 181-199.

Becker, Irene and Richard Hauser. 2005. Dunkelziffer der Armut. Ausmass und Ursachen der NichtInanspruchnahme zustehender Sozialhilfeleistungen. 1. Aufl. Berlin: edition sigma.

BFS. 2013. Regional Portraits and Key Figures for Swiss Communities 2012. Statistischer Sozialbericht Schweiz 2015. Neuchâtel: Bundesamt für Statistik. https://www.bfs.admin.ch/bfs/de/home/ statistiken/regionalstatistik/regionale-portraets-kennzahlen/gemeinden/gemeindeportraets.html (20.02.2018).

BKSE. 2016. Handbuch Sozialhilfe. Berner Konferenz für Sozialhilfe, Kindes- und Erwachsenenschutz (BKSE). http://handbuch.bernerkonferenz.ch/home/ (15.04.2016).

Blank, Rebecca M. 1997. What Causes Public Assistance Caseloads to Grow? NBER Working Paper No. 6343. Cambridge, MA: National Bureau of Economic Research.

Bodenmann, Patrick, Hans Wolff, Thomas Bischoff, et al. 2014. Renoncement aux soins: comment appréhender cette réalité en médecine de premier recours? Revue Médicale Suisse (10): 2258-2263.

Bonvin, Jean-Michel, Felix Bühlmann, Fabrizio Butera, Jörg Dittman, Matthias Drilling, Carlo Knöpfel, Daniel Stöckling, Jean-Pierre Tabin, Anne Perriard, Emilie Rosenstein, Amal Tawfik and Emilio Paolo Visintin. 2015. Welfare Boundaries. Lausanne/Geneva: LIVES.

Braun, Markus and Jan Boruvka. 2016. Angepasste Sozialhilfequote für den Kanton Bern, 2012. Neuchâtel: Bundesamt für Statistik.

Bruckmeier, Kerstin and Jürgen Wiemers. 2012. A New Targeting: A New Take-Up? Empirical Economics 43(2): 565-580.

Champion, Cyrielle. 2011. Switzerland: A Latecomer Catching Up, Pp. 121-142 in Regulating the Risk of Unemployment: National Adaptations to Post-Industrial Labour Markets in Europe, edited by Jochen Clasen and Daniel Clegg. New York: Oxford University Press.

Contzen, Sandra. 2015. «Wir Sind Nicht Arm»! Diskursive Konstruktionen von Armut von Schweizer Bauernfamilien. Journal of Socio-Economics in Agriculture (8): 60-69.

Crettaz, Eric, Thomas Jankowski, Tom Priester, Thomas Ruch, and Lukas Schweizer. 2009. Sozialhilfeund Armutsstatistik im Vergleich. Neuchâtel: Bundesamt für Statistik.

Currie, Janet. 2004. The Take Up of Social Benefits. No. 1103. IZA Discussion Paper Series. http://www.nber.org/papers/w10488 (20.08.2015).

Daponte, Beth Osborne, Seth Sanders, and Lowell Taylor. 1999. Why Do Low-Income Households Not Use Food Stamps? Evidence From an Experiment. Journal of Human Resources 34(3): 612-628.

Eurofond. 2015. Access to Social Benefits: Reducing Non-Take-Up. Luxembourg: Publications Office of the European Commission.

Fivaz, Jan. 2015. Das sozialpolitische Profil des neuen Nationalrats. Soziale Sicherheit CHSS (6): 342-347. 
Fluder, Robert and Jürgen Stremlow. 1999. Armut und Bedürftigkeit: Herausforderungen für das kommunale Sozialwesen. P. Haupt.

Frick, Joachim R. and Olaf Groh-Samberg. 2007. To Claim or Not to Claim: Estimating Non-TakeUp of Social Assistance in Germany and the Role of Measurement Error. SSRN Scholarly Paper, ID 1096449. Rochester, NY: Social Science Research Network. https://papers.ssrn.com/ abstract $=1096449$ (17.02.2018).

Gelissen, John. 2000. Popular Support for Institutionalised Solidarity: A Comparison Between European Welfare States. International Journal of Social Welfare 9(4): 285-300.

Goffman, Erving. 1963. Notes on the Management of Spoiled Identity. New York: Touchstone.

Harrington, Michael. 1962. The Other America; Poverty in the United States. New York: Macmillan.

Hermann, Michael and Heiri Leuthold. 2003. Atlas der politischen Landschaften: ein weltanschauliches Porträt der Schweiz. Zürich: vdf Hochschulverlag AG.

Hernanz, Virginia, Franck Malherbet, and Michele Pellizzari. 2004. Take-Up of Welfare Benefits in OECD Countries: A Review of the Evidence. OECD Social, Employment and Migration Working Papers, No. 17. OECD Publishing. http://dx.doi.org/10.1787/525815265414 (20.08.2015).

Hümbelin, Oliver and Rudolf Farys. 2016. The Suitability of Tax Data to Study Trends in Inequality. A Theoretical and Empirical Review With Tax Data From Switzerland. Research in Social Stratification and Mobility 44: 136-150.

Jaeger, Mads Meier. 2006. What Makes People Support Public Responsibility for Welfare Provision: Self-Interest or Political Ideology? A Longitudinal Approach. Acta Sociologica 49(3): 321-338.

Jann, Ben. 2010. Robuste Regression. Pp. 707-740 in Handbuch Der Sozialwissenschaftlichen Datenanalyse, edited by Christian Wolf and Henning Best. Wiesbaden: VS Verlag für Sozialwissenschaften.

Kayser, Hilke and Joachim R. Frick. 2000. Take It or Leave It: (Non-) Take-Up Behavior of Social Assistance in Germany. 210. DIW Discussion Papers. Berlin: Deutsches Institut für Wirtschaftsforschung (DIW). http://hdl.handle.net/10419/18180 (18.08.2015).

Knüsel, René and Annamaria Colombo. 2014. Accessibilité et non-recours aux services publics. Bruxelles: Les politiques sociales.

Koller, Manuel and Werner A. Stahel. 2011. Sharpening Wald-Type Inference in Robust Regression for Small Samples. Computational Statistics \& Data Analysis 55(8): 2504-2515.

Larsen, Christian Albrekt. 2008. The Political Logic of Labour Market Reforms and Popular Images of Target Groups. Journal of European Social Policy 18(1): 50-63.

Leresche, Frédérique and Jean-Pierre Tabin. 2016. Non-Recours et Travail Social. Actualité sociale (65): $18-19$.

Leu, Robert E., Stefan Burri, and Tom Priester. 1997. Lebensqualität und Armut in der Schweiz. Bern: Haupt.

Linder, Wolf, Regula Zürcher, and Christian Bolliger. 2008. Gespaltene Schweiz-geeinte Schweiz: Gesellschaftliche Spaltungen und Konkordanz bei den Volksabstimmungen seit 1874. Baden: Hier+Jetzt, Verlag für Kultur und Geschichte.

Link, Bruce G. and Jo C. Phelan. 2001. Conceptualizing Stigma. Annual Review of Sociology 27: 363-385.

Lucas, Barbara, Catherine Ludwig, Eric Crettaz, Jérome Chapuis, Audrey Magat, Aude Maryse Bourgeois, and Maxime Walder. 2015. Le non-recours aux prestations sociales à Genève. Genève: Haute école de travail social Genève. https://www.hesge.ch/hets/recherche-developpement/projets-recherche/ en-cours/non-recours-aux-prestations-sociales-geneve (21.02.2018).

MacDonald, Robert, Tracy Shildrick, and Andy Furlong. 2014 ."Benefits Street" and the Myth of Workless Communities. Sociological Research Online 19(3): 1.

Moffitt, Robert. 1983. An Economic Model of Welfare Stigma. The American Economic Review 73(5): 1023-1035. 
Neuenschwander, Peter, Oliver Hümbelin, Marc Kalbermatter, and Rosmarie Ruder. 2012. Der schwere Gang zum Sozialdienst: Wie Betroffene das Aufnahmeverfahren der Sozialhilfe erleben. Zürich: Seismo.

Odenore. 2012. L'envers de la "fraude sociale». Le scandale du non-recours aux droits sociaux. Paris: La Découverte.

Rennwald, Line and Adrian Zimmermann. 2016. Der Wahlentscheid der Arbeiter in der Schweiz, 1971-2011. 4. Social Change in Switzerland. http://socialchangeswitzerland.ch (28.04.2016).

Riphahn, Regina T. 2001. Rational Poverty or Poor Rationality? The Take-Up of Social Assistance Benefits. Review of Income and Wealth 47(3): 379-398.

Roosma, Femke, Wim van Oorschot, and John Gelissen. 2016. The Achilles' Heel of Welfare State Legitimacy: Perceptions of Overuse and Underuse of Social Benefits in Europe. Journal of European Public Policy 23(2): 177-196.

Rousseeuw, P., C. Croux, V. Todorov, A. Ruckstuhl, M. Salibian-Barrera, T. Verbeke, M. Maechler, and M. Koller. 2015. Robustbase: Basic Robust Statistics. R package.

Sage, Daniel. 2012. Fair Conditions and Fair Consequences? Exploring New Labour, Welfare Contractualism and Social Attitudes. Social Policy and Society 11(3): 359-373.

Schuwey, Claudia and Carlo Knöpfel. 2014. Neues Handbuch Armut in der Schweiz. Luzern: Caritas-Verlag.

SKOS. 2016. Das soziale Existenzminimum der Sozialhilfe. Bern: Schweizerische Konferenz für Sozialhilfe (SKOS).

Staerklé, Christian, Tiina Likki, and Régis Scheidegger. 2012. A Normative Approach to Welfare Attitudes, in Contested Welfare States: Welfare Attitudes in Europe and Beyond, edited by Stefan Svallfors. California: Stanford University Press.

Tabin, Jean-Pierre and Frédérique Leresche. 2016. Le non-recours aux prestations sociales, ce mystère. Reiso.org Revue d'information sociale. https://www.reiso.org/articles/themes/politiques/442-le-nonrecours-aux-prestations-sociales-ce-mystere (09.02.2018).

UCLA. 2018. Regression With Stata Chapter 2 - Regression Diagnostics. IDRE Stats: Institute for Digital Research and Education (UCLA). https://stats.idre.ucla.edu/stata/webbooks/reg/chapter2/ stata-webbooksregressionwith-statachapter-2-regression-diagnostics/ (28.02.2018).

Van Oorschot, Wim. 2002. Targeting Welfare: On the Functions and Dysfunctions of Means-Testing in Social Policy. Pp. 171-193 in World Poverty: New Policies to Defeat an Old Enemy, edited by Peter Townsend and David Gorden. Bristol: Policy Press.

Van Oorschot, Wim. 1998. Failing Selectivity: On the Extent and Causes of Non-Take-Up of Social Security Benefits. Pp. 101-132 in Empirical Poverty Research in a Comparative Perspective, edited by H.-J. Andress. Ashgate: Aldershot.

Van Oorschot, Wim. 1991. Non-Take-Up of Social Security Benefits in Europe. Journal of European Social Policy 1(1): 15-30.

Van Oorschot, Wim, Femke Roosma, Bart Meuleman, and Tim Reeskens. 2017. The Social Legitimacy of Targeted Welfare: Attitudes to Welfare Deservingness. Cheltenham, Glos, UK; Northampton, Massachusetts, USA: Edward Elgar Pub.

Wacquant, Loïc. 2009. Punishing the Poor: The Neoliberal Government of Social Insecurity. Durham London: Duke University Press Books.

Walker, Robert, Grace Bantebya Kyomuhendo, Elaine Chase, Sohail Choudhry, Erika K. Gubrium, Jo Yongmie Nicola, Ivar LøDemel, Mathew Leemamol, Mwiine Amon, and Pellissery Sony. 2013. Poverty in Global Perspective: Is Shame a Common Denominator? Journal of Social Policy 42(02): 215-233.

Warin, Philippe. 2016. Le non-recours aux politiques sociales. Grenoble: Presses Universitaires de Grenoble. https://www.pug.fr/produit/1302/9782706125720/Le\%20non-recours\%20aux\%20politiques\%20 sociales $\% 20 \% 20(09.02 .2018)$. 
Whelan, Stephen. 2010. The Take-Up of Means-Tested Income Support. Empirical Economics 39(3): $847-875$.

\section{Appendix}

Table A1 Rental index for MS regions in the Canton of Bern

\begin{tabular}{lc}
\hline MS-Region & Rental index \\
\hline Aaretal & 105.61 \\
Bern & 119.80 \\
Biel/Bienne & 97.96 \\
Burgdorf & 99.08 \\
Erlach-Seeland & 101.53 \\
Grenchen & 87.45 \\
Jura bernois & 76.02 \\
Kandertal & 87.35 \\
La Chaux-de-Fonds & 78.16 \\
Murten/Morat & 108.27 \\
Oberaargau & 91.84 \\
Oberes Emmental & 93.16 \\
Oberland-Ost & 112.45 \\
Saanen-Obersimmental & 140.20 \\
Schwarzwasser & 91.94 \\
Thun & 109.18 \\
\hline
\end{tabular}

Quelle: Own calculations based on the offer prices of rented apartments according to MS-regions, Wüest \& Partner, ImmoMonitoring.

Table A2 VIF values

\begin{tabular}{ll}
\hline Variable & VIF(df) \\
\hline urban/rural & $4.6(2)$ \\
language region & $1.4(1)$ \\
left/right & $2.9(2)$ \\
employees in primary sector & $3.4(1)$ \\
employees in tertiary sector & $2.9(1)$ \\
population density & $5.0(1)$ \\
\% working poor & $1.2(1)$ \\
log (poverty gap) & $1.6(1)$ \\
\hline
\end{tabular}


Figure A-1 Non-take-up quotas of municipalities of the Canton of Bern for different types of municipalities (with outliers)

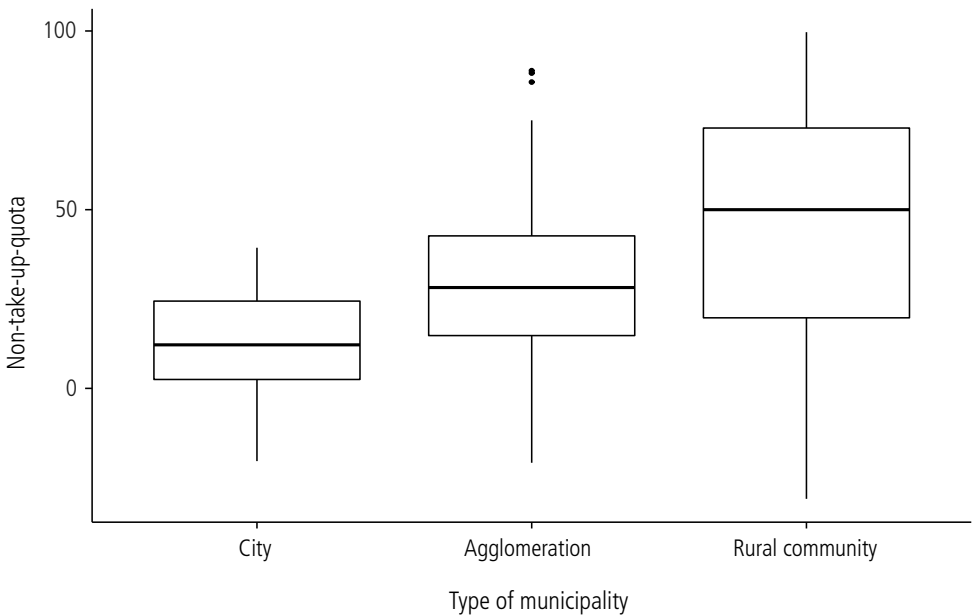

Note: Two cases with strong negative values were excluded for this visual representation because the graph would no longer be sufficiently legible for the relevant area. It could not be determined why these implausible cases with large negative values occurred.

Figure A-2 Non-take-up quotas of municipalities of the Canton of Bern for different types of municipalities (without outliers)

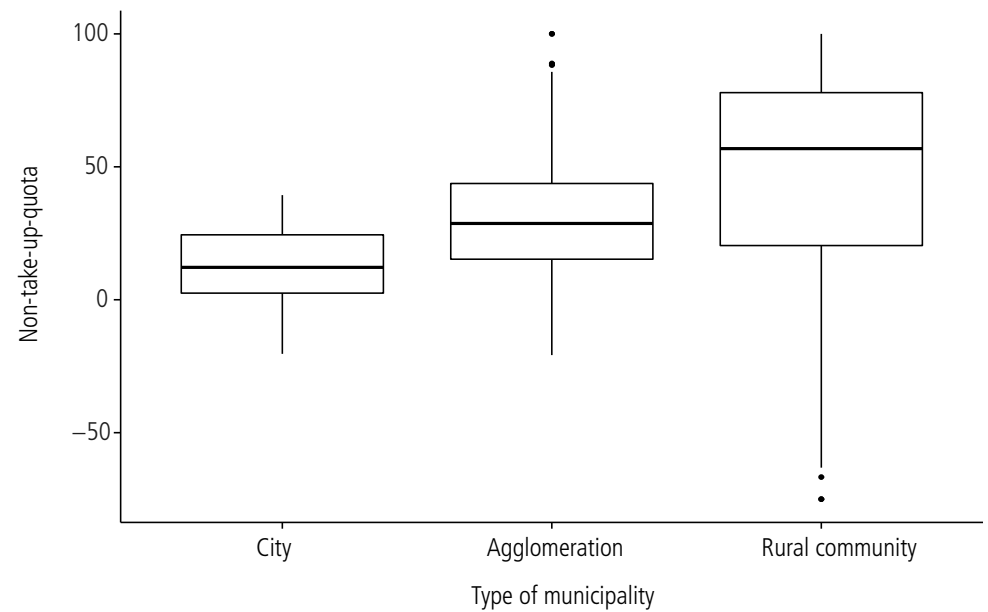

Note: Outliers were eliminated if they exceeded $5 \%$ and $95 \%$ percentiles values. 